\author{
L. N. Vilinskaya I, G. M. Burlak', V. A. Borschak², M. I. Kutalova'2, N. P. Zatovskaya ${ }^{2}$ \\ ${ }^{1}$ Odessa State Academy of Civil Engineering and Architecture, 4 Didrikhson str., Odessa 65029 \\ ${ }^{2}$ Odessa I. I. Mechnikov National University, 2, Dvorianskaya str., Odessa, 650026, \\ E-mail: vilsem56@gmail.com
}

\title{
FEATURES OF APPLICATION OF THE THERMOLUMINESCENT METHOD FOR DATING
}

\begin{abstract}
To determine the age of geological rocks, we studied the thermoluminescence of the natural light sum stored as a result of uncontrolled radioactive radiation, as well as after annealing and exposure to a controlled irradiation dose. The magnitude of the stored light sum was determined from the area under the curve of thermoluminescence. It is shown that the thermoluminescent method allows to accurately determine the age of geological objects and can find practical application for creating sensors of dating.
\end{abstract}

\section{INTRODUCTION}

Thermally stimulated luminescence (TSL) is used in radiation dosimetry to determine the age of archaeological ceramics and geological rocks [1-3]. Since the luminescence is very sensitive to the defects in a solid, it can also be used in material research. The TSL method of dating ceramics and geological objects is based on the fact that, under the action of radioactive radiation of a number of elements in the earth's crust, the light sum is accumulated by the objects under study. The process of storing non-equilibrium charge carriers occurs at local capture levels in dielectrics under the action of ionizing radiation from natural radionuclides contained in the dating object $[1,4]$. During heat treatment of ceramics (880-980 K), quartz contained in it loses all its previously accumulated light sum, the accumulation of which occurred since the formation of quartz as a mineral. Thus, when dating by the thermoluminescent method, a zero-moment is realized, which is undoubtedly the main advantage of this method.

After storing the light sum with the subsequent heating, this energy is released in the form of TSL. The magnitude of the stored light sum is determined by the properties of the samples investigated: porosity, the content of quartz in them, and the dose power received by them. The content of quartz is fundamentally impor- tant, therefore, the application of this method is limited only to those periods, the geological history of which is inherent to quartz-stone. The technique and interpretation of the results of the thermoluminescent method differ for different groups of researchers, that is, they are under development, so the research topic is very relevant.

\section{THERMOLUMINESCENCE EXCITED BY INTERACTION WITH WATER VAPOR}

The use of the TSL method is based on the assumption that the accumulation of the light sum occurs only as a result of the exposure of the test samples to the elements of the geological environment by radiation of the natural radiation background. However, as is well known, the accumulation of a light sum by a number of solids can occur without exposure to ionizing radiation as a result of their interaction with water [5-7]. In this case, the accumulation of the light sum occurs near the surface of a solid. The value of the stored light sum is determined by the value of its specific surface, its state and the nature of the substance itself.

The storage process of the light sum is due to the formation of radical ions, in particular, during the dissociation of water, and their adsorption on the catalytically active centers of the solid surface [7]. Radical ions can come to the 
surface from the environment, or form on the catalytically active surface of a solid as a result of dissociation of the adsorbent. The amount of stored light sum is determined mainly by the number of centers on the surface of a solid on which radical ions can adsorb, creating complexes of adsorption nature that perform the functions of traps filled with electrons.

The process of storing the light sum often ends within a few days, but sometimes it takes much longer to complete. The light sum stored in this way is determined only by the properties and state of the solid surface, while the light sum accumulated under the action of radioactive radiation is due to the processes occurring in its bulk and is determined by the presence of both emission centers and electron traps in the substance under study. Therefore, "surface" luminescence can also manifest itself in the case when the usual "bulk" thermoluminescence is absent. Obviously, the existence of both types of thermoluminescence is also possible. The ratio of their intensities is determined by the nature of the substance, the impurities in it, the value of the specific surface and its properties, the conditions of its keeping, the magnitude of the radiation dose received and its nature.

The presence of such a "surface" thermoluminescence should lead to overestimated values of the rock age, however, it is not taken into account in any way when dating geological objects. It is precisely because of the presence of "surface" thermoluminescence that, apparently, the age of rocks, determined by the authors in the work by the thermoluminescent method [8], is often $1,5 \div 2$ times their age, determined by the radiocarbon method. It is the "surface" component of thermoluminescence that is apparently due to the course of "natural" thermoluminescence of granite in [9], the position of the maximum of which on the temperature scale differs significantly from the position of the maxima of "artificial" thermoluminescence stimulated by $\mathrm{X}$-rays and irradiation in a nuclear reactor. This difference was interpreted by the author in favor of assuming that thermoluminescent dating is not applicable in this case. In our opinion, this fact is a manifestation of the influence of vari- ous types of centers (surface and bulk) on TSL.

Obviously, the presence of "surface" thermoluminescence is largely due to the large difference observed in [10] in the intensities of the "natural" thermoluminescence peaks of apatite within the same array. Indeed, the intensity of "surface" thermoluminescence is determined by the state of the surface, which, in turn, depends significantly on the conditions of the sample, which, of course, within the same array in different parts of it. It is precisely the accumulation of the light sum by the surface of the samples that apparently caused the spontaneous recovery observed in the same work with the thermoluminescence time of the samples after their calcination.

Thermoluminescent dating method is also used in archeology to determine the age of ceramics $[1,2,10,11]$. The method is based on the application for dating quartz, extracted from or contained in ceramics. As with dating in geology, it is believed that the light sum is stored only as a result of irradiation of samples with radioactive radiation. However, usually on quartz, as well as on ceramics, the surface is very strongly developed. The specific surface is often tens and hundreds of square meters per $1 \mathrm{~g}$ of substance. Since there are usually $10^{13}$ centers per $1 \mathrm{~cm}^{2}$ of the surface of a solid, capable of performing the functions of traps filled with electrons (complexes of adsorption nature), there will be $10^{19}$ in $1 \mathrm{~g}$ of such centers. Provided that impurities capable of performing the functions of deep electron traps in the bulk of a solid body are $10^{-2}$, we find that the number of such centers per gram of substance is $10^{19}$.

Thus, the numbers of both types of centers can be commensurate, and in some cases the number of surface centers can significantly exceed the number of bulk centers. Accordingly, the intensity of the "surface" luminescence is commensurate with the intensity of the "bulk". Since the use of the thermoluminescent method assumes the presence of only "bulk" thermoluminescence, while the total is recorded, it is obvious that a significant error is possible when dating in this way, and therefore, just like when dating geological objects, it is necessary to take 
into account the "surface" component of luminescence.

The given examples testify to the manifestation of the "surface" component of thermoluminescence in a number of geological objects and indicate the need to take it into account when dating by the thermoluminescent method. The spectral composition of the luminescence that arises when the light sum stored as a result of exposure to water is determined by the luminescence centers located near the surface of the samples. These centers can also be largely associated with the adsorption of water. The spectral composition of the luminescence arising from the thermoluminescence of the light sum stored during radioactive irradiation is determined mainly by the luminescence centers located in the sample volume. Such centers can be impurities of a number of metals, lattice structure defects, etc.

Thus, since the nature of the centers responsible for the emission of "surface" and "volume" luminescence may be different, the spectra of these two types of luminescence may also differ. The aim of the work was to study the spectral composition of "natural" thermoluminescence induced by radioactive radiation and thermoluminescence excited when interacting with water. Such information may provide additional information for determining the age of geological rocks.

\section{EXPERIMENTAL}

Taking into account the above considerations on the role of water and the surface component of luminescence, the method [8-14] of thermoluminescent dating can be somewhat changed. At the first stage, the curve of thermoluminescence of a prepared archaeological or mineralogical object should be removed. The area under the curve of thermoluminescence gives the value of the natural light sum, accumulated as a result of uncontrolled radioactive radiation.

At the second stage, the previously highlighted sample is heated at a temperature of $970-1070 \mathrm{~K}$ to erase the remnants of the progenetic amount, which could remain unreleased as a result of the previous measurement. Since thermostimulated luminescence associated with surface states is strongly influenced by the products of the dissociation of water and some other inorganic substances, such a measurement should be carried out in a vacuum, atmosphere of dry air or inert gases. At the third stage, the sample is exposed to a controlled dose of radiation, after which thermoluminescence is again performed. All studies known to us at this stage were carried out without isolating the samples from moisture, as a result of which the latter, together with the irradiation, stored the light sum. It gave the overestimated value of the total light sum and, as a result, the overestimated age of the rocks. Comparing the light sum, obtained under the action of natural uncontrolled irradiation and controlled dose, you can determine the age of the sample.

It is known that the intensity of thermoluminescence is proportional to the radiation dose [15]:

$$
I_{n a t}=C P_{1} t_{1}
$$

$P_{1}$ - natural dose power (natural background), $t_{1}$ - age of geological rocks, $C$ - constant, independent of the power and time of exposure. Similarly, the intensity of the TSL, which is observed as a result of irradiation with a controlled dose of radiation, is induced by the TSL:

$$
I_{\text {ind }}=C P_{2} t_{2}
$$

where $P_{2}$ is the dose power control, $t_{2}$ is the exposure time $C$ - constant, which does not depend on the power and time of exposure. Hence the age of the rocks:

$$
t_{1}=\frac{I_{n a t} P_{2} t_{2}}{P_{1} I_{\text {ind }}}
$$

The accuracy of dating is determined by both the accuracy of the method and the possibility of the temporary separation of various geological rocks. The accuracy of the TSL method is quite high [16]. The possibility of temporary separation of various rocks is determined by geological laws and is not less than 200-300 years. 
We carried out thermoluminescent dating of quartz samples. Quartz was chosen for the reason that, being a mineral, it is also present in archaeological samples and, moreover, as can be seen from the previous one, due to the presence of quartz, the thermally stimulated dating of archaeological rocks is possible.

By the method of wet sieve analysis, fractions of $100-140 \mu \mathrm{m}$ in size were determined from quartz rock sediments previously identified by radiocarbon analysis with different periods of the quaternary period. Quartz was extracted by mineral separation in heavy liquids (bromoform). Degree of purity is $98-99 \%$. Surface cleaning from contamination was carried out by processing in a $10 \% \mathrm{HF}+\mathrm{HCl}$ solution for 10 minutes. The obtained samples were pressed into tablets with a diameter of $12 \mathrm{~mm}$ and a thickness of $2 \mathrm{~mm}$.

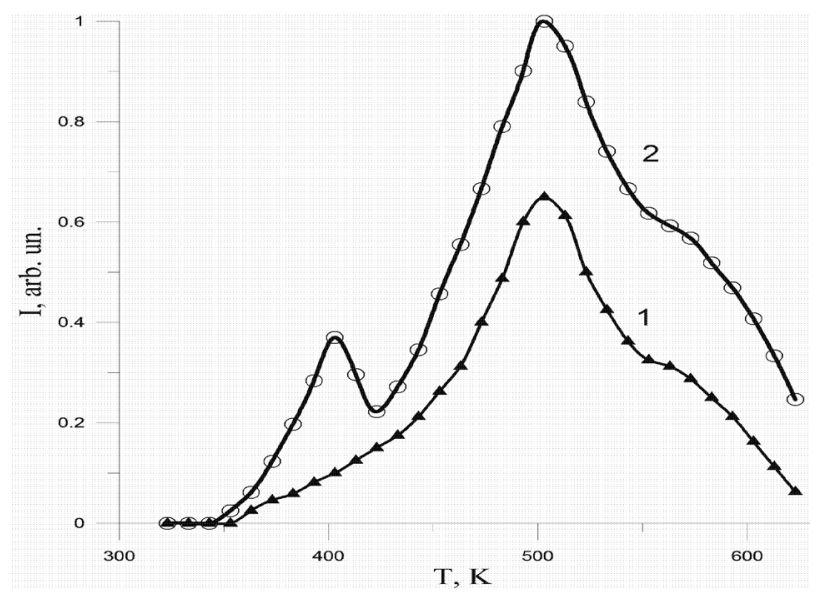

Fig.1. Curves of thermoluminescence of samples: 1) the intensity of the natural light sum stored as a result of uncontrolled radioactive radiation; 2) the intensity of the light sum after heating at a temperature of $970-1070 \mathrm{~K}$ and the effects of a controlled dose of radiation.

For measurements, a standard thermoluminescent installation was used in the integral sensitivity mode (the signal was amplified by an IMT-005 direct current meter and fed to one of the coordinates of the recording device). The temperature was measured using a copper - constantan thermocouple with an accuracy of $10 \mathrm{~K}$ and was fed to another coordinate of the recording device (PDP-001). The heating rate was $0,3 \mathrm{~K} / \mathrm{min}$. The working volume of the chamber in which the thermolumination was carried out was hermetically sealed and purged with vapors of dry air, the humidity level in which did not exceed $0.05 \%$. The source of exposure was cobalt ${ }^{60} \mathrm{Co}$ (power $0,15 \mathrm{x}$-ray / s). The measurements were carried out in the temperature range from $320-600 \mathrm{~K}$. The curves of thermoluminescence are shown in fig. 1.

\section{RESULTS AND DISCUSSION}

It can be seen that all samples are characterized by peaks in the range of 500-525 $\mathrm{K}$ and about $580 \mathrm{~K}$, which correspond to peaks of quartz and calcite. For samples exposed to a controlled dose of radiation, the intensity of the light sum increased and an additional peak appeared at a temperature of $400 \mathrm{~K}$. The total value of the stored light sum was determined by the area under the curve of thermoluminescence. The age of the rocks was determined similarly to the formula given above:

$$
t_{1}=\frac{I_{i c d} D_{a}}{I_{\text {ind }} D_{a}}
$$

The annual dose of radioactive radiation included in this formula $\mathrm{D}_{\text {an }}$ was determined by the value of the natural background radiation. The accumulated dose $\mathrm{D}_{\text {ac }}$ was determined taking into account the power of the source. $I_{i c d}$ - the intensity controlled radiation dose rate

(induced TSL), $I_{i n c}$ - the intensity of the uncontrolled radiation dose (natural background).

The age estimate taking into account the experimental data obtained is $2,6 \cdot 10^{4}$ years. The radiocarbon analysis of the same sample gives $2,1 \cdot 10^{4}$ the age of years. A good agreement of the results obtained by two different methods may indicate the validity of the assumption that the coefficient of proportionality is constant between the intensity of the TSL and the radiation dose power. This circumstance indicates the possibility of practical application of the samples under study to create dating sensors.

To determine the age of geological rocks, we studied the thermoluminescence of the natural light sum stored as a result of uncontrolled radioactive radiation, as well as after warming up 
and exposure to a controlled irradiation dose. A good agreement was obtained between the results obtained by thermoluminescent and radiocarbon methods. It is shown that the discrepancy between the results obtained by these methods is less than that given by other authors. Obviously, this improvement was due to the inclusion of the "surface" component of thermoluminescence. The above dating method allows you to accurately determine the age of geological and archaeological objects and can find practical application for creating dating sensors.

\section{REFERENCES}

1. Hashimoto T. An overview of redthermoluminescence (RTL) studies on heated quartz and RTL application to dosimetry and dating // Geohronometria. 2008. Vol. 30 (1). P. 9-16. https://doi. org/10.2478/v10003-008-0011-z

2. Richter D., Richter A., Dornich K. Lexsyg smart-A luminescence detection system for dosimetry, material research and dating application. Geochronometria. 2015; 42:202-209. doi: 10.1515/geochr-2015-0022.

3. Murthy K.V.R. Thermoluminescence and its Applications: A Review. Defect Diffus. Forum. 2013; 347:35-73. doi: 10.4028/www.scientific.net/DDF.347.35.

4. Власов, В. К. Радиотермолюминесцентный метод датирования рыхлых отложений / В. К. Власов, О. А. Куликов. - М.: Издательство Московского университета, 1998. - 72 с. 5. Михо В.В., Дмитренко З.Ф. К вопросу о применеии метода термовысвечивания для изучения параметров активных центров// Кинетика и катализ. 1998. - т.19. -№3. C.720-724.

6. Федчук А.П., Михо В.В. Определение характера активных центров в окиси алюминия методом темровысвечивания // Кинетика и катализ. 1994. -Т.15. -№2. -C.534-535.

7. Танабе К. Твердые кислоты и основания. М.:Мир. 1993, 176 с.

8. Шелкопляс В. Н. Применение термолюминесцентного (ТЛ) метода для датирования плейстоценовых образований.
// Хронология плейстоцена и климатическая стратиграфия. - Л. - 1993. - С. 121 - 127.

9. Хютт Г., Пуннинг Я.-М., Смирнов А. Методика термолюминесцентной датировки в геологии. // Изв. АН ЭССР. Сер.: химия, геолог. - 1997. - Т. 26, №4. - С. 284 - 288.

10. Чистяков В. К. Особенности природной и искусственной термолюминесценции апатита из интрузивных и метамерфических пород. // Изв. АН СССР. Сер.: геолог. - 1994. - № 8. - С. 81 - 90 .

11. Комарова, Я. М. Термолюминесцентный метод датирования археологических объектов / Я. М. Комарова, Н. Л. Алукер, А. С. Сыроватко // Изв. ВУЗов. Физика. - 2011. - Т. 54. - № 2/2. - С. 191-195.

12. V.S. Grinevych, L.M. Filevska, V.A. Smyntyna, M.O. Stetsenko, S.P. Rudenko, L.S. Maksimenko, and B.K. Serdega. Characterization of $\mathrm{SnO}_{2}$ Sensors Nanomaterials by Polarization Modulation Method. Springer Science+Business Media Dordrecht 2016 J. Bonca, S. Kruchinin (eds.), Nanomaterials for Security, NATO Science for Peace and Security Series A: Chemistry and Biology, DOI 10.1007/978-94-017-7593-9, p.259-266.

13. L.M. Filevska. Luminescence of nanoscale tin dioxide. Review. Photoelectronics. 27 (2018), p.52-59.

14. Лепіх Я.І., Лавренова Т.I., Садова Н.М., Борщак В.А. Балабан А.П., Затовська Н.П. Структурно-фазові перетворення і електрофізичні властивості композиційних матеріалів на базі системи " $\mathrm{SiO}_{2}-\mathrm{B}_{2} \mathrm{O}_{3}-\mathrm{Bi}_{2} \mathrm{O}_{3}-\mathrm{ZnO}$ $\mathrm{BaO} " / /$ Sensor electronics and Microsystem Technologies. - 2018- Vol.15, № 4 - PP. 77-84. 15. Иванов В.П. Курс дозиметрии. М.:Атомиздат, 1998. -391 c.13. https://www. ncbi.nlm.nih.gov/pmc/articles/PMC5744292/ 16. Adrie J.J.Bos Thermoluminescence as a Research Tool to Investigate Luminescence Mechanisms. Material (Basel). 2017 Dec; 10(12): 1357. doi: 10.3390/ma10121357 
UDC 550.93

L. N. Vilinskaya, G. M. Burlak, V. A. Borschak, M. I. Kutalova, N. P. Zatovskaya

\section{FEATURES OF APPLICATION OF THE THERMOLUMINESCENT METHOD FOR DATING}

To determine the age of geological rocks, we studied the thermoluminescence of the natural light sum stored as a result of uncontrolled radioactive radiation, as well as after warming up and exposure to a controlled irradiation dose. The magnitude of the stored light sum was determined from the area under the curve of thermoluminescence. It is shown that the thermoluminescent method allows one to accurately determine the age of geological objects and can find practical application for creating dating sensors.

Keywords: thermoluminescent method, dating, storage of light sum, thermoluminescence.

УДК 550.93

Л. Н. Вилинская, Г. М. Бурлак, В. А. Борщак, М. И. Куталова, Н. П. Затовская

\section{ОСОБЕННОСТИ ПРИМЕНЕНИЯ ТЕРМОЛЮМИНЕСЦЕНТНОГО МЕТОДА ДЛЯ ДАТИРОВАНИЯ}

Для определения возраста геологических пород проведено изучение термовысвечивания естественной светосуммы, запасенной в результате неконтролируемого радиоактивного излучения, а также после прогрева и воздействия контролируемой дозы облучения. Величина запасенной светосуммы определялась по площади под кривой термовысвечивания. Показано, что термолюминесцентный метод позволяет достаточно точно определять возраст геологических объектов и может найти практическое применение для создания сенсоров датирования.

Ключевые слова: термолюминесцентный метод, датирование, запасание светосуммы, термовысвечивание.

УДК 550.93

Л. М. Вілінська, Г. М. Бурлак, В. А. Борщэак, М. І. Куталова, Н. П. Затовська

\section{ОСОБЛИВОСТІ ЗАСТОСУВАННЯ ТЕРМОЛЮМИНЕСЦЕНТНОГО МЕТОДУ ДЛЯ ДАТУВАННЯ}

Для визначення віку геологічних порід проведено вивчення термовисвітлення природної світлосуми, що запасена в результаті неконтрольованого радіоактивного випромінювання, а також після прогріву і впливу контрольованої дози опромінення. Величина запасеної світлосуми визначалася за площею під кривою термовисвітлення. Показано, що термолюмінесцентний метод дозволяє досить точно визначати вік геологічних об'єктів і може знайти практичне застосування для створення сенсорів датування.

Ключові слова: термолюмінесцентний метод, датування, запасання світлосуми, термовисвітлення. 